\title{
AVOIMEN YLIOPISTON HISTORIAN MURROSKOHDAT
}

\author{
Kirjoittaja on analysoinut avointa yliopistoa koskevaa julkipuhetta \\ avoimen yliopiston kolmikymmenvuotisen historian aikana ja löytänyt \\ siitä neljä eri perusdiskurssia. Niiden kautta on pyritty määrittämään \\ avoimen yliopiston asemaa yliopistomaailmassa. Diskurssien avulla \\ kirjoittaja hahmottelee artikkelissaan avoimen yliopiston historiallisia \\ murroskohtia. Murroskohdissa jokin aikaisempi "ongelma” saa ratkai- \\ sunsa, mutta samalla syntyy jokin uusi jännite.
}

NINAHALTTUNEN

A voin yliopisto on ollut yliopistojen aikuiskoulutusmuotona olemassa yli 30 vuotta. Yliopistollisia arvosanoja tai niiden osia suorittaa avoimessa yliopistossa nykyisin vuosittain noin 85000 ihmistä. Tarkastelen tässä artikkelissa avoimen yliopiston historiaa sekä sen paikan rakentumista yliopistokoulutuksen kentällä. Tutkimuksessa käyttämäni aineisto koostuu erilaisista teksteistä ja dokumenteista, joita avoimeen yliopistoon sidoksissa olevat toimijatahot ovat tuottaneet.

Koska avoin yliopisto on organisaatioltaan ja toteutustavoiltaan muotoutunut hyvin monimutkaiseksi verkostomaiseksi rakenteeksi, on siihen sidoksissa olevia toimijatahoja useita. Avoimen yliopiston paikan määritykseen ovat osallistuneet mm. "varsinaiset” yliopistot ja niiden akateeminen väki, avointa yliopistoa ja sen opiskelijoita tarkastelleet tutkijat, yliopistojen perustutkintoopiskelijat, täydennyskoulutuskeskukset ja niissä työskentelevät avoimen yliopiston toteuttajat ja kehittäjät, opetusministeriö sekä kesäyliopistot ja muut aikuiskoulutusta järjestävät organisaatiot. Analysoitavat tekstit ovat avointa yliopistoa koskevaa julkipuhetta, kuten komiteoiden ja työryhmien mietintöjä sekä erilaisia raportteja ja selvityksiä. Tärkeänä aineistoryhmänä ovat lisäksi lehtikirjoitukset, jotka on kerätty systemaattisesti muutamista keskeisistä aikakausijulkaisuista. Kirjoitukset edustavat erilaisia tekstityyppejä. Myös tutkimustekstit ovat analyysin kohteena, sillä ne määrittävät avoimen yliopiston paikkaa ja avoimen yliopiston opiskelijuutta yhdessä mui- den tekstien kanssa.

Olen analysoinut tekstimassasta esiin neljä eri diskurssia. (1) Yliopistollisuuden diskurssi korostaa korkeakoulutuksen erityisluonnetta muuhun koulutukseen verrattuna. Tästä diskurssista käsin avoin yliopisto erityisesti laajentuessaan muodostaa uhan perinteisille akateemisille arvoille. (2) Sivistyksellisen tasa-arvon diskurssi korostaa koulutuksen merkitystä demokratian kannalta ja kantaa eri-

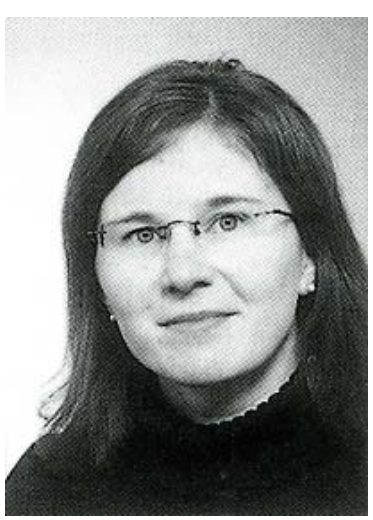

Nina Halttunen tyistä huolta huonompiosaisten koulutusmahdollisuuksista. Diskurssissa painottuu koulutusmahdollisuuksien tarjoaminen siten, että kaikki väestöryhmät pystyisivät käyttämään niitä hyväkseen. (3) Joustavuuden diskurssi korostaa avoimen yliopiston tehtävää erilaisten yksilöllisten tarpeiden tyydyttäjänä. Tehtävänä on lisätä tasa-arvoa, mikä tapahtuu laajentamalla opetustarjontaa ja lisäämällä mahdollisuuksia erilaisiin joustaviin opiskelumuotoihin. (4) Kehittämisen diskurssi rakentaa avointa yliopistoa eräänlaisena tuotekehittelylaboratoriona. Opetusmenetelmien kehittäminen sekä avoimen yliopiston statuksen kohottaminen ja yliopistollinen imago ovat tärkeitä.

Käsittelen avoimen yliopiston historiaa neljän eri murroksen kautta. Murrokset ovat taitekohtia, joissa rakenteiden tai tapahtumien tasolla on erotettavissa muutoksia. Ne merkitsevät siten 
muutoksia myös niissä konteksteissa, joissa avointa yliopistoa koskevia diskursiivisia määrittelyitä tuotetaan. Murrosten yhteydessä todellisuus ja sitä koskeva ymmärrys järjestyvät uudella tavalla. Jokin aikaisempi ongelma saa "ratkaisunsa” ja lakkaa olemasta, mutta jokin uusi jännite vastaavasti syntyy.

Ensimmäinen murros, jonka olen nimennyt avoimen yliopisto synnyksi, ajoittui 1970-luvun alkupuoliskolle. Avoin yliopisto sai vakiintuneet puitteensa vasta 1980-luvun puolivälissä, jolloin se organisoitiin osaksi yliopistojen täydennyskoulutusta. Tämä voidaan nähdä avoimen yliopiston historian toisena murroksena, jonka olen nimennyt toiminnan ja toiminta-ajatuksen muotoutumiseksi. Kolmas murros ajoittui 1990-luvulle, jolloin avoimen yliopiston resursointi muuttui ja nuoret tulivat sen näkyväksi opiskelijaryhmäksi. Tämä avoimen yliopiston uudelleenmuotoiluksi nimeämäni murros problematisoi avoimen yliopiston ja tutkintokoulutuksen suhteen aiemmasta poikkeavalla tavalla. Olemmekin juuri nyt neljännen murroksen kynnyksellä, kun yliopistojen tutkinnonuudistus pian toteutuu. Nähtäväksi jää, millaiseksi avoimen yliopiston asema uudenlaisessa tutkintojärjestelmässä ja -järjestyksessä muotoutuu.

\section{MURROS:}

\section{TOINEN MAHDOLLISUUS YLIOPISTON REUNALLE}

Suomalainen yliopistolaitos oli aina 1960-luvulle asti varsin suljettu ja ulkopuolisilta vaikutuksilta turvassa. Yliopiston "rajamaastoon” (ks. Kantasalmi 2001) versosi kuitenkin joitakin toimintamuotoja, jotka voidaan nähdä eräänlaisina avoimen yliopiston esimuotoina. Näistä kaikkein lähimpänä avointa yliopistoa olivat kesäyliopistot, joiden toiminta-ajatuksena oli ensisijaisesti kesäaikaisen opetuksen antaminen ylioppilaille, mutta joiden opetus oli samalla avointa myös muille. 1950-luvulla ja etenkin 1960-luvun puolelle tultua kesäyliopistoverkko alkoi nopeasti tihentyä. (Karjalainen \& Toiviainen 1984.)

Kesäyliopistojen määrän nopea lisääntyminen määrittyi yliopistoväen keskuudessa ongelmaksi. 1950-luvulla ja osin vielä 1960-luvullakin elettiin akateemis-traditionalistisen korkeakouludoktriinin aikaa, jolloin yliopistomaailman sisäinen järjestys perustui lähinnä Helsingin yliopiston määräävään asemaan ja professorien ylittämättömään valtaan (Kivinen, Rinne \& Ketonen 1993). Nämä keskeiset yliopistopolitiikan toimijat katsoivat opetuksen laajentamisen yliopistojen ulkopuolelle vaarantavan opetuksen yliopistollisen tason (esim. KM 1962: 34).

Kesäyliopistojen perustaminen ei ollut muusta korkeakoulupolitiikasta irrallinen ilmiö, vaan se kytkeytyi hyvin voimakkaasti uusien yliopistojen perustamiseen ja laajemminkin yliopistomaailman sisäisen järjestyksen uudelleenmuotoutumiseen. 1960- ja 1970-luvuilla suomalainen yliopistolaitos kävi läpi voimakkaan myllerryksen, jonka lopputulemina olivat mm. yliopistokoulutuksen alueellinen laajentuminen, opiskelijamäärien voimakas kasvu, tutkintojen uudistaminen sekä korkeakoulutuksen tiukentunut sidos valtiovallan ohjaukseen (Kivinen, Rinne \& Ketonen 1993).

Avoin yliopisto sai alkunsa näiden muutosten kanssa samanaikaisesti. Se ei kuitenkaan ollut millään muotoa näiden melskeiden keskiössä, joskin korkeakoulutuksen yleinen käymistila ja puhe koulutusdemokratiasta olivat muokanneet maaperää otolliseksi avoimen yliopiston ajatukselle. Idea avoimesta yliopistosta tuli meille ulkomailta. Englannissa oli koko 1960-luvun ajan suunniteltu uuden, mullistavan eetteriyliopiston perustamista. Kun Open University vuonna 1969 perustettiin, seurattiin uuden yliopiston vaiheita Suomessakin kiinnostuneina. OU oli innoittava esikuva monelle suomalaiselle, jotka vaikuttuivat erityisesti tavasta, jolla etäopetusta järjestettiin laajoille osallistujajoukoille. (Esim. Rantavaara 1973; Blomstedt 1972.)

Avoimen yliopiston käsite tuli näin keskusteluun, mutta muuntui tarkoittamaan monenlaisia asioita. Avoin yliopisto näyttäytyi keskustelussa myös yleisesti ottaen melko abstraktina käsitteenä, joka ymmärrettiin eri yhteyksissä eri tavoin. Etenkin yliopisto-opiskelijat omaksuivat avoin yliopisto -sanan käyttöönsä ja tarkoittivat sillä mm. mm. ei-ylioppilaiden oikeutta hakeutua yliopisto-opiskelijaksi. Ideaa tuotiin esille jopa niin laajana kysymyksenä, että avoin yliopisto tulisi toteuttaa koko korkeakoululaitoksessa kaiken opetuksen ja tiedon demokratisointina. (esim. KM 1972:A17.)

Ymmärrettiin käsite sitten miten tahansa, siihen liitettiin aina hyvin voimakkaasti ajatus koulutuksellisesta ja sivistyksellisestä tasa-arvosta. Keskustelussa mukana olleet tahot näyttivät olevan näiden tavoitteiden saavuttamisen tarpeellisuudesta varsin samanmielisiä. Keskustelun pe- 
rusjännite muodostui yliopistollisuutta korostavan diskurssin ja sille haastajaksi nousseen sivistyksellisen tasa-arvon diskurssin välisestä suhteesta. Näiden positioiden välillä vallitsi yksimielisyys erityisesti siitä, että avoin yliopisto oli tarkoitettu aikuisille ja ei-ylioppilaille. Erimielisiä oltiin kuitenkin sen suhteen, miten avoin yliopisto tätä koulutusdemokratian tavoitetta palvelisi. Pelko siitä, ettei opetus kohdistuisi tarkoitetuille ryhmille, oli yliopistollisuutta korostaville toimijoille aihe epäillä koko toiminnan mielekkyyttä. Samalla nämä toimijat painottivat sitä, että avoimen yliopiston suoritusten tuli tasoltaan ja statukseltaan olla täysin vastaavia yliopistojen perusopetuksen kanssa. "Mitään yliopistotutkintojen alennustavarataloahan ei avoimesta yliopistosta saa tulla", kuten opetusministeri Ulf Sunqvist (1972) totesi.

Helsingissä yliopiston konsistorin tehtäväksiannosta professori Yrjö Blomstedt laati selvityksen avoimen yliopiston toteuttamiseen liittyneistä kysymyksistä. Tässä hyvin keskeisen aseman saaneessa tekstissä on selkeästi läsnä tuon ajan keskustelulle laajemminkin ominainen jännite: yhtäältä katsottiin, että avoimen yliopiston tuli olla eräänlainen irtiotto akateemisen maailman elitismistä, mutta toisaalta painotettiin, että tämä ei kuitenkaan saanut merkitä opetuksen tasosta tai yliopistollisuudesta tinkimistä. Erottavana tekijänä kesäyliopistotoimintaan verrattuna painotettiin eksplisiittisesti sitä, että avoimen yliopiston tehtävänä tuli olla tasa-arvon lisääminen. Yrjö Blomstedt muotoili asian niin, ettei avoimesta yliopistosta saanut tulla toisen luokan yliopistoa, vaan sen piti olla toisen mahdollisuuden yliopisto. (Blomstedt 1972.)

Avoin yliopisto jäi kuitenkin muiden aiheiden varjoon, eikä akateeminen yhteisö laajemmassa mitassa antautunut keskustelulle avoimesta yliopistosta. Myöskään poliittiset päättäjät eivät kiinnostuneet avoimesta yliopistosta siinä määrin, että olisivat ryhtyneet asiassa aloitteellisiksi. Kun Britanniassa Open University syntyi suuren mittaluokan hankkeena, maan poliittisen johdon määrätietoisesti ajamana (Perry 1976), todellistui idea Suomessa aivan eri tavoin. Käytännössä toiminta alkoi paikallisina hankkeina pienimuotoisesti yliopiston "reunamilla”.

Ensimmäisenä avoimen yliopiston nimellä annettava arvosanaopetus alkoi Tampereen yliopiston täydennyskoulutuskeskuksen järjestämänä vuonna 1971. Suomeen ensimmäisenä perustettu täydennyskoulutuskeskus otti toisena toimintavuotenaan ohjelmaansa avointa korkeakouluopetusta, josta tuli heti varsin suosittua. (Laakko 1974.) Vastaperustettu Joensuun korkeakoulu aloitti avoimen korkeakoulun opetuksen vuonna 1972 yhteistyössä alueen opistojen kanssa (Antikainen 1974). Myös Jyväskylän yliopisto alkoi lukuvuodesta 1971-72 järjestää avointa yliopisto-opetusta (Entonen \& Lyytinen 1979). Nämä hankkeet erottautuivat nimensä ja jossakin määrin toiminta-ajatuksensa puolesta kesäyliopistoista. Ensimmäisinä vuosina kaikilla avoimeksi yliopistoksi tai korkeakouluksi kutsutuilla kursseilla oli yhteenlaskien arviolta noin 2500 opiskelijaa. Samaan aikaan valtaosa yliopistollisesta arvosanaopetuksesta annettiin kesäyliopistoissa (KM 1972: B57, liitteet 6-7).

Ensimmäisen murrosvaiheen lopputulemana avoin yliopisto syntyi avoimeksi yliopistoksi nimettyjen kurssien järjestämisenä. Tämä oli yksi vastaus ajan demokratiahaasteeseen sekä korkeakoulutukselle langenneeseen vaatimukseen laajentaa sisäänpääsyä määrällisesti ja alueellisesti. Avoin yliopisto oli syntynyt, mutta pienenä ja pirstaleisena, ilman keskusta ja ilman selvää suuntaa toiminnan valtakunnallisesta organisoinnista, joten tilanne jäi monelta osin hyvin avoimeksi.

\section{MURROS:}

\section{PUITTEET LYÖDÄÄN LUKKOON}

$\mathrm{A}$ voin yliopisto oli konkreettisena toimintana saanut alkunsa yliopiston reunamilla ja myös ilman keskushallinnon aloitetta tai puuttumista asiaan. Se, että avoin korkeakoulu oli olemassa jonkinlaisena konkreettisena toimintana, mutta kuitenkin ilman vakiintunutta toimintamallia tai keskusjohtoista ohjausta, oli hedelmällinen tilanne keskustelulle. Se saattoi nyt kiinnittyä empiiriseen todellisuuteen, mutta koska toiminta vielä haki uomiaan, oli käyty vuoropuhelu varsin vilkasta ja moniäänistä.

Avoimen korkeakoulun kokeilutoiminta alkoi vilkastua. Ennen 1970-luvun loppua suurimmat hankkeet käynnistyivät Turun ja Helsingin yliopistoissa, ja 1980-luvun puolella kaikki muutkin monialaiset yliopistot aloittivat tämän toiminnan. Selvä raja kulki suhteessa erityiskorkeakouluihin. Oppiaineista suosituimpia olivat kasvatustieteelliset ja yhteiskuntatieteelliset aineet. (KM 1981: 36.) Samalla kun avoin korkeakoulu todellistui yliopistojen reunamille, myös avoimesta yliopis- 
tosta käyty keskustelu siirtyi entistä selvemmin omalle saarekkeelleen, irti yleisemmästä korkeakoulukeskustelusta. Tästä kertoo mm. tutkintoopiskelijoiden vetäytyminen pois keskustelusta.

Keskustelussa pohdittiin erityisesti korkeakoulutuksen ja avoimen korkeakoulun avoimuutta, jota määritettiin sekä sivistyksellisen tasa-arvon että joustavuuden diskursseista käsin. Koulutukselliseksi tasa-arvoksi määrittyi ennen kaikkea se, että eri väestöryhmille tarjottiin mahdollisuutta osallistua korkeakoulutasoisiin opintoihin. Samalla kun teksteissä rakennettiin avoimen yliopiston tehtävää, tuotettiin niissä myös kuvaa tuon tehtävän toteutumisesta. Keskustelussa todettiin, ettei avoimen korkeakoulun avoimuus ollut toivotussa määrin toteutunut. Sivistyksellistä tasa-arvoa korostavasta positiosta käsin ongelmaksi nähtiin, että opetukseen osallistuminen ei välttämättä kohdentunut tarkoitetulla tavalla. Esimerkiksi professori Juhani Karvonen oli huolissaan "ns. heikompiosaisten yleisestä passiivisuudesta" ja totesi avoimuuden yhden ulottuvuuden, koulutuksen tavoitettavuuden, toteutuvan "vasta sitten, kun asianomainen haluaa tavoittaa sen" (Karvonen 1978).

Myös tutkimusteksteillä osallistuttiin tähän keskusteluun. Suurin osa opiskelijoista oli tehtyjen selvitysten mukaan naisia ja alle 30-vuotiaita. Ylioppilaita oli keskimäärin hieman alle puolet kursseille osallistuneista. Varsin monet olivat ilman ammatillista koulutusta, mutta niillä, joilla oli jokin ammatillinen tutkinto, se oli useimmin opistotasoinen. Tutkijat katsoivat avoimen yliopiston tässä mielessä toteuttaneen tehtäväänsä huonosti. (esim. Antikainen 1974; Laakko 1974.) Tampereen yliopiston järjestämään opetukseen osallistuneita tutkinut Laakko pohti kysymystä, "miten saada houkutelluksi opetuksen pariin niitä henkilöitä, joilla ei vielä ole pitkää peruskoulutusta. Nyt näyttää siltä, että täydennyskoulutuskeskuksesta on vaara muodostua takaportti sellaisille ylioppilaille, jotka eivät ole mahtuneet sisälle korkeakouluihin. Toinen kysymys on sitten se, missä määrin eksplisiittisesti ilmaistu periaate 'opetuksen korkeakoulutasoisuudesta' ehkä pelottaa pois pienemmän peruskoulutuksen omaavia opiskelijoita. Tällaisille ryhmillehän ei keskuksessa ole tarjottu minkäänlaista tukiopetusta. Tässä laadullisen demokratisoinnin lisäämisessä on vielä paljon tehtävää.” (Laakko 1974, 34.)

Joustavuutta korostavasta diskurssista käsin ongelmaksi nähtiin mm. resurssit ja niiden mahdollistama opetuksen laajuus. Etäopetuksen kehittämisen välttämättömyyttä perusteltiin tästä positiosta käsin tarpeella säästää opettajien aikaa ja matkustusta (esim. Rinta-Kanto 1980). Yliopiston akateemisen maailman sisältä esitettiin argumentteja hyvin toisenlaisesta näkökulmasta mm. sen puolesta, että avoimuuden lisäämisellä olisi vaaransa ja että "minkäänlainen pääsykriteereiden liberalisoiminen ei saa päästä vaikuttamaan koulutustulosten tasoa madaltavasti” (Mannerkoski 1979).

Avoimen yliopiston yhteistyöverkosto oli hiljalleen muotoutumassa omalla painollaan sitä mukaa, kun uusia yliopistoja tuli toimintaan mukaan. Käydyssä keskustelussa tulivat esille tähän liittyvät kysymykset, kun pohdittiin mm. avoimen yliopiston toiminnan organisointia yliopistojen sisällä (esim. Seppälä 1983). Erityisen vilkkaasti keskustelua käytiin opistokentällä. Kansanopistoista sekä kansalais- ja työväenopistoista oli tullut olennainen osa opetuksen järjestämiseen tarvittavaa yhteistyöverkkoa, mutta suhteessa avoimeen korkeakouluun podettiin tietynlaista identiteettikriisiä. Kansalaisopistokentän pelkona oli, että niiden edustamat arvot ja ideologiat "uhrataan approbaturin alttarille" (Tuominen 1982). Opistojen näkökulmasta avoimen korkeakoulun arvosanakeskeisyys saattoi muodostua myös tasa-arvon esteeksi, sillä nämä opinnot olivat monille liian vaikea ponnistus esimerkiksi puutteellisen kielitaidon takia. Opistokentällä katsottiinkin, että sen tehtävänä oli omalta osaltaan olla "avaamassa tietä avoimeen korkeakouluun" (Tuomikoski 1980).

Avoimen korkeakoulun marginaalisuutta valtiovallan näkökulmasta kuvastaa osaltaan se, että ensimmäisen komitean asetti Suomen Kulttuurirahasto. Mietinnön julkistaminen vuonna 1976 sai kuitenkin myös opetusministeriön aktivoitumaan avoimen korkeakoulun asiassa ja mm. asettamaan oman toimikuntansa pohtimaan sen organisaatiota ja toteutusta. Näiden kahden toimikunnan mietinnöt ovat olleet voimakkaasti määrittämässä avoimen korkeakoulun paikkaa ja tehtäviä. Ne mm. "virallistivat” avoimen korkeakoulun tehtäväksi sivistyksellisen tasa-arvon ja koulutuksellisen demokratian edistäminen. Katsottiin myös, että koulutus oli erityisesti suunnattu aikuisväestölle, minkä vuoksi toimikunnat suosittivat osallistumiselle 25 vuoden ikärajaa. (Avoin korkeakoulu 1976; KM 1981: 36.) 
Organisaation muotoutumisen kannalta merkittävä teksti oli vuosille 1983-86 hyväksytty korkeakoululaitoksen kehittämissuunnitelma, jolla opetusministeriö naulasi ne puitteet, joissa avoin korkeakoulu tuli jatkossa toimimaan. Avoimen korkeakoulun paikka määritettiin diskursiivisesti osaksi yliopistojen täydennyskoulutustoimintaa ja käytännön tasolla yliopistojen täydennyskoulutuskeskusten toteuttamaksi toiminnaksi. Samalla kesäyliopistot rajattiin pois toiminnan keskiöstä. (OPM 1983.) Merkkinä uuteen vaiheeseen siirtymisestä opetusministeriö antoi lisäksi korkeakouluille vuonna 1984 ensimmäiset ohjeet avoimen korkeakoulun järjestämisestä rakentaen tällä tekstillään toiminnan vakiintuneisuutta (OPM 1984).

Avoimen yliopiston toimintamalli oli nyt "lyöty lukkoon”. Ensimmäisen murroksen jäljiltä avoin yliopisto oli ollut ajelehtivassa tilanteessa, jossa sen organisaatio ja tehtävänjako olivat määrittelemättä. Toinen murros ratkaisi nämä ongelmat vakiinnuttamalla avoimen korkeakoulun järjestelmän puitteet. Toiminnan kannalta keskeinen kysymys jäi kuitenkin vielä auki. Miten tulisi ratkaista ongelma avoimen yliopiston resursoinnista ja maksuista? Tämä loi perusjännitteen toisen murroksen jälkeiseen aikaan.

\section{MURROS:}

\section{MARKKINOISTUMISEN LÄPILYÖNTI}

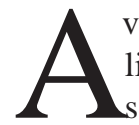
voin korkeakoulu oli 1980-luvun puoliväliin mennessä saavuttanut aseman, jossa sen olemassaoloa sinänsä ei enää vakavasti kyseenalaistettu, mutta jossa symboliset taistelut sen paikasta osana yliopistojen toimintaa jatkuivat. Käytännön toimintana avoin korkeakoulu kehittyi niissä puitteissa, jotka sille nyt oli luotu. Täydennyskoulutuskeskuksia oli 1980luvun loppuun mennessä perustettu jokaiseen korkeakouluun (Heikkilä, Salmela \& Kurki 1990). Opiskelijamäärä kasvoi vakaasti. Vuonna 1986 opiskelijoita oli reilut 26000 ja vuonna 1992 oli jo ylitetty reilusti 60000 opiskelijan raja (KOTA). Opetusta järjestettiin erityisesti monitieteisissä yliopistoissa sekä kasvatus- ja yhteiskuntatieteellisissä oppiaineissa. Opiskelijajoukko näytti pysyneen taustoiltaan samana kuin aikaisemminkin. Lukuisissa avoimen yliopiston opiskelijoita koskeneissa tutkimuksissa rakennettiin kuvaa tyypillisestä opiskelijasta: hyvän perus- ja ammatilli- sen koulutuksen omaavasta nuorehkosta naisesta, joka työskenteli opetus-, terveydenhoito- tai sosiaalialalla. (esim. Varila 1990.)

Kun aikaisemmin oli keskusteltu vilkkaasti avoimen korkeakoulun tehtävästä ja merkityksestä, tapahtui keskustelussa nyt käänne. Sivistyksellisen tasa-arvon painotukset jäivät muiden diskurssien - erityisesti toiminnan laajentamista painottavan joustavuuden diskurssin varjoon. Kokonaisuudessaan avointa korkeakoulua leimasi resurssien niukkuus ja kilpailun kiristyminen eri järjestäjätahojen kesken, ja samalla puheenaiheet kiinnittyivät tiiviimmin taloudellisiin kysymyksiin. Maksut olivat esillä niin opiskelijoilta perittävinä maksuina kuin organisaatioiden toisiltaan periminä yhteistyömaksuinakin. Opiskelijamaksujen osalta opetusministeriön tavoitteena oli tuoda maksut myös täydennyskoulutuskeskusten järjestämään avoimeen korkeakouluopetukseen, mutta tätä koskenut esitys kaatui eduskunnassa. (Jäppinen 1987.) Käytännössä maksujen perimiselle ei kuitenkaan ollut estettä. Opetusministeriö mm. totesi kirjeessään korkeakouluille, että “korkeakoulu voi tietenkin myydä oppimateriaalia myös avoimeen korkeakouluopetukseen osallistuville opiskelijoille” (OPM 1986). Täydennyskoulutuskeskusten muilta aikuiskoulutusorganisaatioilta perimiin yhteistyömaksuihin liittyneillä ohjeilla opetusministeriö rakensi samalla järjestäjätahojen välistä kilpailuasetelmaa. Nämä maksut aiheuttivat närää eri toimijatahojen välille (ks. esim. Julkunen 1991), ja erityisesti kesäyliopistojen toimintatila kaventui täydennyskoulutuskeskusten saatua koordinoivan aseman avoimen korkeakouluopetuksen järjestämisessä (esim. Ryönänkoski 1996).

Englannin esikuvan mukaisesti avoimen korkeakoulun idea rakentui osaltaan erilaisten opetusmenetelmien ja -teknologioiden kehittämisen varaan, mutta tämä toiminta oli käytännön tasolla kuitenkin jäänyt Suomessa melko vaatimattomaksi. Opetus oli lähiopetusta, jota toteutettiin kansan-, kansalais- ja työväenopistoissa. Tämän opetuksen järjestämistavan kestämättömyyttä korostivat erityisesti opetusministeriö ja täydennyskoulutuskeskukset, joiden välinen diskursiivinen liittouma näkyi käytännön tasolla opetusministeriön rahoittamina ja täydennyskoulutuskeskusten toteuttamina etäopetuksen kehittämishankkeina (OPM 1989: 59, liite 3). Resurssikysymysten ratkaisemattomuus näkyi myös opetusmenetelmistä käydyssä keskustelussa. Uusien 
menetelmien tärkeyttä perusteltiin alkuvaiheessa erityisesti tästä näkökulmasta. Mm. puhelinopetuksen mahdollisuuksiin uskottiin vakaasti ja todettiin, että sen avulla voitiin "säästää kallisarvoisia opettajaresursseja ja tehdä mahdolliseksi se, ettei täsmälleen samaa opetusta tarvinnut toistaa eri opetuspisteissä” (Larsen 1987). Samaa asiaa perusteltiin myös tasa-arvon lisääntymisellä, kun joustavilla opiskelumahdollisuuksilla voitiin "vähitellen tarjota koulutusta aivan uusille, tähän saakka syrjäytyneille väestöryhmille” (Larsen 1988).

Pian uutta pedagogiikkaa alettiin näiden joustavuuden diskurssista kumpuavien argumenttien lisäksi kuitenkin perustella myös kehittämisdiskurssista käsin mm. paremmilla oppimistuloksilla. Erotuksena perinteiseen opetukseen monimuoto-opetukselle luonteenomaisena haluttiin nähdä “painopisteen siirtäminen pintaoppimista suosivasta opetus- ja tenttikäytännöstä laajempien ja syvällisemmin hallittujen tietokokonaisuuksien omaksumisen mahdollistavaan opiskeluun" (Koro 1989). Teknologiasta ja opetusmenetelmistä käyty keskustelu ilmentää osaltaan erottautumisen ja samastumisen ristiriitaa suhteessa yliopistoon (vrt. Herranen 2003). Tässä näkyy kehittämisen diskurssille ominainen sisäinen jännite siinä, että samalla kun tuotiin esille avoimen korkeakoulun innovoivuutta ja edelläkävijyyttä suhteessa yliopistojen tutkintokoulutukseen, oli kuitenkin tärkeätä korostaa oppimistulosten laadukkuutta nimenomaan vastaavuutena perusopetukseen.

1990-luvun alussa nopeasti syventynyt lama ja korkealle kohonneet työttömyysluvut olivat osaltaan vaikuttamassa avoimen yliopiston julkilausutussa tehtävässä tapahtuneeseen muutokseen. Muutos ei ollut yhtäkkinen, vaan 1980-luvun aikana pikkuhiljaa edenneet tapahtumat ja siirtymät olivat raivanneet tietä uudelle. Lopullisena taitoksen merkkinä olivat ns. Relander-rahat, joita vuonna 1993 suunnattiin myös avoimeen korkeakouluopetukseen. Tämän lisäresurssin ansiosta avoimen korkeakoulun rahoitusrakenne muuttui radikaalisti (ks. OPM 1996: 7). Opiskelijamäärä kohosi nopeasti, mikä tapahtui lähes yksinomaan täydennyskoulutuskeskusten itse järjestämän opetuksen voimakkaan kasvun ansiosta. Täydennyskoulutuskeskusten asema avoimen korkeakouluopetuksen järjestäjien kentällä vahvistui nyt siten myös määrällisesti mitattuna. Vuonna 1993 saatiin päätökseen lisäksi pitkään vireillä ollut maksuja koskenut valmistelutyö, kun opetusministeriö antoi niitä koskeneen päätöksensä (SA 83/1993). Käytännössä päätös vahvisti jo vallitsevaksi muodostuneen käytännön.

Relanderin rahojen julkilausuttuna tarkoituksena oli auttaa surkeaan jamaan joutunutta nuorisotyöttömyyttä (Relander 1992), joten tämän ohjelman yhteydessä ikärajat avoimen yliopiston kursseilta poistettiin. Alusta asti oli avoimeen korkeakouluopetukseen suosituksena olleista ikärajoista huolimatta kuitenkin osallistunut myös nuoria henkilöitä. Alle 25-vuotiaiden osuus oli ennen ikärajojen poistamista vuonna 1992 ollut vajaa neljäsosa (Seppälä 1994), mikä vuoteen 1995 mennessä nousi noin kolmannekseen (Rinne, Jauhiainen, Tuomisto, Alho-Malmelin, Halttunen \& Lehtonen 2003). Huolimatta siitä, että nuoret olivat "perinteisestikin” osallistuneet avoimeen korkeakouluopetukseen erityisesti kansanopistoissa, löydettiin heidät keskustelussa nyt täysin uutena opiskelijaryhmänä, jonka sisäänmarssi avoimeen yliopistoon määrittyi hyvin dramaattiseksi muutokseksi. Mm. tutkijat alkoivat noteerata nuoret omana ryhmänään. Heidät otettiin erikseen tarkastelun kohteeksi ja todettiin mm. huomattavan tutkintotavoitteisiksi. (esimerkiksi Piesanen 1996.)

Nuorisotyöttömyyteen avoimen korkeakoulun opetus ei käytännössä vaikuttanut. Avoimessa korkeakoulussa opiskelun aloittava työtön nuori ei siirtynyt opintotuen piiriin, joten vaikutus työllisyyteen saattoi olla vain välillinen. (Hallituksen lisäkoulutusohjelman...) Joka tapauksessa nuorten rajaaminen tämän koulutusmuodon ulkopuolelle oli alkanut käydä yhä vaikeammaksi, ja nuorisotyöttömyys tarjosi legitiimin syyn vihdoin poistaa ikärajat. Muutos entiseen nähden ei opiskelijoiden toteutuneen ikärakenteen suhteen siten ollutkaan yhtä suuri kuin se muutos, joka tapahtui julkilausutussa toimintapolitiikassa.

Kolmannen murroksen seurauksena avoin yliopisto laajeni, sen resursointi kasvoi huomattavasti samalla kun yliopistojen perusrahoitusta leikattiin, täydennyskoulutuskeskukset voimistuivat eikä nuorten osallistumiselle avoimeen yliopisto-opetukseen enää ollut muodollisia tai moraalisia esteitä. Nämä muutokset yhdessä nostivat voimakkaasti esille kysymyksen avoimen yliopiston ja tutkintokoulutuksen välisestä suhteesta. Tästä tulikin kolmannen murroksen jälkeisen ajan perusjännite, joka kiteytyi tutkintoväylää koskevassa keskustelussa. 
IV MURROKSEN KYNNYKSELLÄ: SUUNTA KOHTI TYÖELÄMÄÄ?

$\mathrm{T}$ utkintoväylä oli tekstien tasolla ollut olemassa jo 1980-luvun alkupuoliskolta alkaen ja erityisesti 1990-luvulla avointa yliopistoa oli alettu teksteissä rakentaa väylänä korkeakoulututkintoon (esim. OPM 1993). Väylä ei käytännön tasolla kuitenkaan muotoutunut määrällisesti merkittäväksi eikä se myöskään tullut laajemman keskustelun kohteeksi ennen 1990-luvun puoliväliä. Opetusministeriö asetti nyt valintamenettelyyn liittyneitä kysymyksiä pohtimaan työryhmän, joka asettui voimakkaasti kritikoimaan yliopistojen käytäntöjä joustavuutta korostavasta diskurssipositiosta käsin. Perusteluiksi väylän kehittämisen tarpeelle työryhmä esitti tuloksellisuusdoktriinin hengessä mm. erilaisia kustannuslaskelmia ja korosti avoimesta yliopistosta tutkinto-opiskelijoiksi siirtyvistä aiheutuvien kustannusten pienuutta. (OPM 1996: 7.)

Väylään, kuten yleisemminkin avoimeen yliopistoon ja sen laajenemiseen kohdistui nyt voimakas kritiikin aalto. Etenkin yliopistojen tutkinto-opiskelijat reagoivat voimakkaasti ns. "automaattiväylän” avaamiseen. Kritiikin ytimessä oli edelleen ajatus akateemisen tason laskusta massojen tunkeutuessa yliopistoon. (esim. Ylioppilaslehti 1995/16.) Vastustus yltyi tässä vaiheessa aikaisempaa kärjekkäämmäksi, mikä tulee ymmärrettäväksi sillä, että Relanderin rahojen ansiosta avoimen yliopiston resursointi oli kasvanut huomattavasti samaan aikaan kun perusopetuksen resursseja oli leikattu. Kun opetusministeriö tässä tilanteessa selvästi ilmaisi halunsa laventaa väylää, asettuivat yliopistojen tutkinto-opiskelijat puolustamaan yliopistollisia arvoja.

Ikärajojen poisto ja siitä seurannut muutos toimintapolitiikassa tarkoittivat myös tasa-arvokäsityksen muutosta. Kun aiempi kirjoittelun valtavirta oli korostanut ikäluokkien välisen tasaarvon suhteen opiskelumahdollisuuden tarjoamista aikuisille, määrittyi nyt tasa-arvoa loukkaavaksi se, että jokin ryhmä haluttiin ikänsä takia sulkea opintojen ulkopuolelle. Täydellistä tasaarvoa edusti mahdollisuus, joka oli täysin avoin, ilman rajoituksia. Siirtymä sivistyksellistä tasaarvoa painottavasta diskurssista joustavuutta painottavaan diskurssiin oli tapahtunut jo toisen murroksen jälkeen, mutta ikärajojen poisto sinetöi tämän siirtymän käytäntöjen tasolla. Samalla ideologinen täyskäännös suhteessa nuoriin nä- kyy siinä, että avoimessa yliopistossa alettiin tehdä aktiivisesti yhteistyötä lukioiden kanssa mm. pyrkimyksenä käyttää avointa yliopistoa nuorten rekrytointikanavana yliopistoon. (ks. esim. Puttonen 1995.)

Uudessa ideologiassa painottui vahvasti yksilöllisyyden korostaminen. Tasa-arvoidean keskiöön tuli nyt yksilö, joka "koulutuksen kansalaismarkkinoilla" (ks. Yliopistotieto 1998/1) teki koulutusvalintoja ja käytti erilaisia "oppimispalveluja" (esim. Lindqvist 1994) omien tarpeidensa ja mieltymystensä mukaan. Keskustelun perusjännite olikin nyt siirtynyt pois yliopistollisuuden ja sivistyksellisen tasa-arvon diskurssien välisestä suhteesta, kun yliopistollisuutta korostavan position vastinpareiksi olivat tulleet joustavuutta sekä kehittämisen tärkeyttä painottavat diskurssit. Tämä siirtymä tarkoitti samalla myös kielellisten käytäntöjen tasolla tapahtunutta koulutuksen markkinoistumista ja eräänlaisen myynninedistämiskulttuurin omaksumista avoimen yliopiston toiminnassa (ks. Fairclough 1993).

Uutta tasa-arvokäsitystä rakensi myös uusiin opetusmuotoihin sidottu uusi oppimiskäsitys antaessaan keskeisen aseman “oppija”yksilölle, joka itsenäisenä subjektina teki valintoja ja oppi omien halujensa mukaan. Tämän oppimiskäsityksen mukaan järjestetyn opetuksen paremmuutta todistettiin myös väitöskirjatasoisella tutkimuksella (Koro 1993). Yliopistojen akateemisesta positiosta käsin etäopetusta kuitenkin kritikoitiin. Mm. Jari Eskola kirjoitti avoimen yliopiston opetuksesta "kakkoslaatuna" todeten, että avoimen yliopiston "oppimistulokset eivät voi olla kilpailukykyiset tiedekunnan opiskelutuloksiin verrattuna tai sitten tiedekuntaopetuksessa hukataan opetusresursseja melkoisesti” (Eskola 1998).

1990-luvun loppua lähestyttäessä terävin kärki avoimen yliopiston vastustuksesta hiljentyi samalla kun sen ekspansiivinen kasvu tasaantui. On arvioitu, että avoin yliopisto olisi tullut lähemmäs varsinaista yliopistoa. Tämä näkyy mm. avoimen yliopiston resursoinnin siirtämisenä osaksi yliopistojen perusrahoitusta ja avoimen yliopiston sisällyttämisenä uuteen yliopistolakiin osaksi yliopistojen kolmatta tehtävää. (Kess, Hulkko, Jussila, Kallio, Larsen, Pohjolainen \& Seppälä 2002; OPM 2002: 26.) Avoimen yliopiston paikka määrittyy kuitenkin edelleen marginaaliin. Yliopistollisuutta painottavasta positiosta käsin tätä tuotetaan mm. tutkintoväylään liitty- 
villä kannanotoilla (ks. Suuntana sivistys 2003). Samalla myös toiminnan kehittäjien ja opetusministeriön kiinnittyminen kehittämistä korostavaan diskurssipositioon rakentaa avoimen yliopiston paikkaa samansuuntaisesti, sillä tässä diskurssissa avoimen yliopiston legitimiteetti määrittyy nimenomaan "varsinaisen” yliopiston kautta. Joustavuuden ja kehittämisen diskurssit taas ovat keskenään liittolaisia vahvistaen ja oikeuttaen toinen toisiaan.

Nämä diskursiiviset painotukset näkyivät voimakkaasti vuonna 2001 avoimessa yliopistossa toteutetussa valtakunnallisessa arvioinnissa. Arviointiryhmä painotti raportissaan erityisesti opetuksen laadun arvioinnin ja parantamisen tärkeyttä, sillä niillä turvattiin tämän koulutuksen yliopistollisuus. Lisäksi korostettiin avoimen yliopiston tasa-arvotehtävää, mutta todettiin samalla, että pelkkä avoimuuden lisääminen, johon avoimen yliopiston toiminta käytännössä perustui, ei välttämättä lisännyt tasa-arvoa. Arviointiryhmä suosittikin avoimille yliopistoille "erityisesti tasaarvotavoitetta tukevia innovatiivisia ratkaisuja markkinoinnissa” ja totesi, että opetuksen lisäämisellä tietyissä oppiaineissa voitiin tavoittaa "aliedustettuja ryhmiä”, joina arviointiryhmä nosti esille erityisesti miehet. (Kess ym. 2002; ks. myös Jäppinen 2004.)

Arviointiryhmä näki erityisenä ongelmana myös sen, että tutkintoväylä oli edelleenkin pysynyt hyvin ahtaana: vuonna 2000 yhteensä noin 600 avoimen yliopiston opiskelijaa eli 0,7 prosenttia sen kaikista opiskelijoista oli siirtynyt väylää pitkin tutkinto-opiskelijaksi (Kess ym. 2002). Yliopistojen sisäänottopolitiikassa väylä onkin jätetty marginaaliseksi. Viime vuosina väylä on alkanut saada uutta kehystystä tuloksellisuuspuheesta, jossa korostetaan erityisesti opintoaikojen lyhentämistä. Kun nuorten vastavalmistuneiden ylioppilaiden sisäänotto-osuutta halutaan kasvattaa, nostetaan väylä muille tarkoitettuna reittinä tälle vastapainoksi. Avoimesta yliopistosta käydyssä keskustelussa väylä onkin tullut etualalle ja väylän kautta avoin yliopisto on työntynyt myös yleisempään koulutuspoliittiseen keskusteluun. (esim. OPM 2002: 26; OPM 2002: 3; OPM 2003: 27.) Tässä keskustelussa on iduillaan mahdollinen uusi (viides) diskurssi, jossa keskeiseen asemaan nousevat tuloksellisuuteen liittyvät seikat. Samalla työelämä ja sen asettamat vaatimukset ovat tulleet mukaan avoimesta yliopistosta ja väylästä käytyyn keskusteluun. Mm. opintoaikoja pohtinut työryhmä katsoi, että avoimen yliopiston väylää tulisi "helpottaa erityisesti niillä aloilla, joilla on suuri työvoimatarve” (OPM 2003: 27). Myös ylijohtaja Arvo Jäppinen (2004) on ennakoinut avoimen yliopiston aseman tulevan "yliopistojen ja työelämän rajapintana entistäkin keskeisemmäksi".

Käytännön toimintana avointa yliopisto-opetusta järjestetään nykyisin lähes kaikilla yliopistoissa edustettuina olevilla aloilla, vaikka perinteisesti suositut kasvatus- ja yhteiskuntatieteet edelleen ovatkin suurimmat oppialat. Opiskelijamuotokuvassa ei myöskään viime aikoina ole tapahtunut suuria muutoksia. Naisenemmyys opiskelijoiden joukossa on edelleen hyvin vahva ja opiskelijoiden keski-ikä on vähän alle 30 vuotta. Samalla kun väestön koulutustaso on noussut, on myös avoimen yliopiston opiskelijoiden joukossa ylioppilaiden ja korkeakoulututkinnon suorittaneiden osuus kasvanut. Nuorimmissa ikäluokissa avoimen opiskelijat ovat usein päätoimisia opiskelijoita. Ammatissa toimivista varsin suuri osa on eri oppilaitosten opettajia, sosiaali- tai terveysalalla työskenteleviä tai toimistotyötä tekeviä alempia tai ylempiä toimihenkilöitä. Tutkimus, jossa ensimmäisen kerran on tutkittu avoimen yliopiston opiskelijamuotokuvaa valtakunnallisesti, antaa viitteitä myös siitä, että avoimen yliopiston opetustarjonta olisi jakautunut opiskelijoiden taustan mukaan ns. korkeamman ja matalamman statuksen aloihin. (Rinne ym. 2003.)

Lähi- ja monimuoto-opetuksen rinnalle ovat uusimpana kerroksena työntyneet ja työntymässä erilaiset verkko-opiskelun variantit. Monimuoto-opetus on suhteessa tutkintokoulutukseen määrittynyt keskustelussa raja-alueeksi, jonka laadukkuudesta on kiistelty. Verkko-opetus ei ole nostattanut yhtä näkyvää vastakkainasettelua avoimen ja tutkinto-opetuksen välille, vaan näyttäisi siltä, että verkko-opiskelun tielle on lähdetty yhtäläisesti - joskin vielä varovaisesti - molemmilla yliopistokoulutuksen alueilla. Tutkimuksen mukaan verkko-opiskeluun osallistuvat ovat myös korkeammin koulutettuja ja korkeammassa asemassa kuin muut avoimen yliopiston opiskelijat (Rinne ym. 2003). Yhtäältä verkko-opetus ja toisaalta tutkintoväylä ovatkin ne tekijät, jotka linkittyneinä rahoitusjärjestelmään ovat kaikkein vahvimmin määrittämässä avoimen yliopiston suhdetta tutkintokoulutukseen ja potentiaalisesti voimakkaimmin kuljettamassa avointa yliopistoa kohti yliopistokoulutuksen valtavirtaa. 


\section{LOPUKSI}

Avoimen yliopiston synty liittyi sivistyksellisen tasa-arvon diskurssista kumpuavaan vastarintaan vanhaa akateemis-traditionalistista yliopistomaailmaa kohtaan. Avoin yliopisto realisoitui lopulta yliopiston reunamille pienimuotoisesti järjestettäväksi toiminnaksi. Tämän ensimmäisen murroksen jälkeen toimintamalli haki vielä lopullista muotoaan ja keskustelu oli tässä vaiheessa varsin rikasta ja moniäänistä. Yliopistollisuuden diskurssi edusti perinnettä, jota muut diskurssit haastoivat kukin omalta taholtaan. Kun toiminnan ja toiminta-ajatuksen muotoutumisen seurauksena avoimen yliopiston organisatoriset puitteet oli lyöty lukkoon, rajautui keskustelu koskemaan enemmän rahoitukseen liittyviä kysymyksiä. Samalla sivistyksellistä tasa-arvoa korostava diskurssi menetti painoarvoaan. Avoimen yliopiston uudelleenmuotoilu ratkaisi resurssiongelman, mutta nosti samalla esille kysymyksen avoimen ja tutkinto-opiskelun välisestä suhteesta. Siirtyminen uuteen tutkintojärjestelmään merkitsee todennäköisesti neljättä murrosta avoimen yliopiston historiassa. Nähtäväksi jää, millaiseksi reitiksi tutkinto-opintoihin avoin yliopisto muodostuu. Todennäköistä on myös, että nyt orastavana keskustelussa näkyvä tuloksellisuusdiskurssi vahvistuu ja siihen liittyen avoimen yliopiston suhde työelämään tulee uudeksi avointa yliopistoa määrittäväksi perusjännitteeksi.

Erilaisten diskursiivisten käytäntöjen ja määrittelyjen puristuksessa avoimen yliopiston asema on aina ollut ristiriitainen. Diskursseissa ja niiden välisissä jännitteissä on paljolti kyse avoimen yliopiston akateemisuudesta vs. ei-akateemisuudesta ja rajanvedosta "varsinaisen” ja avoimen yliopiston välillä. Avoimen yliopiston marginaalista asemaa tuottaa myös se, että opetusta järjestetään eniten erityisesti oppiaineissa, jotka ovat olleet muutenkin akateemisuuden rajamaastosta käytävässä kamppailussa, kuten kasvatustieteessä. Avoin yliopisto on hyvin silmiinpistävästi myös naisten aluetta yliopistossa. Tähän liittyykin osaltaan pyrkimys laajentaa opetustarjontaa esimerkiksi miehiä kiinnostavilla aloilla ja siten nostaa avoimen yliopiston arvostusta. Yliopistollinen imago ei määrity pelkästään opetuksen tason, vaan myös oppiaineiden ja opiskelijakunnan kautta.

Avoimen yliopiston historiaa voidaan kuvata myös tietynlaisena markkinoistumiskehityksenä.
Toteutunut opetus on aina enemmän tai vähemmän määräytynyt kysynnän ja tarjonnan lakien mukaan. Markkinoistumisen eteneminen näkyy kuitenkin paitsi kilpailun kiristymisenä opiskelijoista ja resursseista, myös kielen ja diskursiivisten käytäntöjen muutoksena. Kiinnittyessään yhä voimakkaammin imagoa painottavaan kehittämisen diskurssiin avoin yliopisto on omaksunut yritysmäisen identiteetin. Koulutus on muuttunut palveluksi, tiedotus markkinoinniksi ja opiskelijat asiakkaiksi.

Missä määrin nämä muutokset ja jännitteet sitten ovat tapahtuneet vain avoimessa yliopistossa? Samanlaiset prosessit lienevät käynnissä niin perus- ja jatkokoulutuksessa kuin tutkimuksessakin eli niillä yliopiston alueilla, jotka suhteessa avoimeen määrittyvät yliopiston ytimeksi. Elinkeinoelämän asettamat paineet ja tuloksellisuusvaatimukset saattavat koskettaa muita yliopiston alueita jopa huomattavasti painokkaammin kuin avointa yliopistoa, joka kuitenkin toistaiseksi on määrittynyt työelämästä varsin irralliseksi alueeksi. Avoimen yliopiston kohtalonkysymykseksi muotoutuukin tulevaisuudessa se, miten tutkintoväylän merkitys käytännössä realisoituu samalla, kun yliopistojen koko tutkintojärjestelmä on uudistusten kohteena. Mikäli avoin yliopisto näissä muutoksissa onnistuu kurkottamaan marginaalista kohti ydintä, tulee se samalla kuitenkin taas uusien, sen ulkopuolelta määräytyvien määrittelyiden kohteeksi.

\section{LÄHTEET}

Antikainen, A. (1974) Selvitys avoin korkeakoulu -hankkeen vaiheista 1972-73 ja näkökohtia kokeilua ja tutkimusta varten. Joensuun korkeakoulun Kasvatustieteiden osaston julkaisuja 1.

Avoin korkeakoulu. Suomen Kulttuurirahaston Avoimen korkeakoulun toimikunnan mietintö. Helsinki 1976.

Blomstedt, Y. (1972) Avoin yliopisto. Helsingin yliopiston konsistorin toimeksiannosta laadittu selvitys 1971-72.

Entonen, T. \& Lyytinen, H.K. (1979) Avoimen yliopiston toimivuus kasvatustieteen opetuksessa. osaraportti I. Jyväskylän yliopiston laitoksen sivutoimintapisteissä kasvatustieteen approbatur-arvosanaa suorittavien opiskelijoiden opiskelumotiiveista ja opiskeluun liittyvistä arvoista. Jyväskylän 
yliopisto. Kasvatustieteen laitoksen tutkimusraportteja 85.

Eskola, J. (1998) Kakkoslaadun loppu vai alku? Aikuiskasvatus 18 (1), 74-76.

Fairclough, N. (1993) Critical discourse analysis and the marketization of public discourse: the universities. Discourse and Society 4 (2), 133-168.

Hallituksen lisäkoulutusohjelman tavoitteet, toimeenpano ja tulokset. Nk. Relander-koulutusrahat työvoimapoliittisin perustein toteutettuun koulutukseen. Valtiontalouden tarkastusviraston tarkastuskertomus 16/1995.

Heikkilä, E.-M., Salmela, H. \& Kurki, L. (1990) Yliopistojen laajennusliikkeestä osaksi multiversityä. Teoksessä O. Kivinen \& R. Rinne (toim.) Korkeakoulut aikuiskoulutusmarkkinoilla. Koulutussosiologian tutkimusyksikön tutkimusraportteja 5. Turun yliopisto, 33-75.

Herranen, J. (2003) Ammattikorkeakoulu diskursiivisena tilana. Järjestystä, konflikteja ja kaaosta. Joensuun yliopisto. Kasvatustieteellisiä julkaisuja 85.

Julkunen, M. (1991) Palvelun saajan kustannettava osuutensa. Opistolehti 68 (3), 3, 24.

Jäppinen, A. (1987) Kansainvälinen tausta ja suomalainen rahoitusratkaisu. Korkeakoulutieto 4, 6-8.

Jäppinen, A. (2004) Puhe Helsingin yliopiston Avoimen yliopiston avajaisjuhlassa 22.4. 2004. Opetusministeriö. Koulutus- ja tiedepolitiikan osasto.

Kantasalmi, K. (2001) Finnish University Adult Education. Expoliring the Social Impacts and Effectiveness in a Historical Context. In S. Kontiainen \& K.E. Nurmi (eds.) Effectiveness of Adult Education. Historical and Evaluative Studies in Finland. University of Helsinki. Department of Education, 7-61.

Karjalainen, E. \& Toiviainen, T. (1984) Suomen vapaan kansansivistystyön vaiheet. Weilin+ Göös.

Karvonen, J. (1978) Mitä korkeakoulun avoimuus voi tarkoittaa? Opistolehti 7, 180-185.

Kess, P., Hulkko, K., Jussila, M., Kallio, U., Larsen, S., Pohjolainen, T. \& Seppälä, K. (2002) Suomen avoin yliopisto. Avoimen yliopistoopetuksen arviointiraportti. Korkeakoulu- jen arviointineuvoston julkaisuja 6. Edita.

Kivinen, O., Rinne, R. \& Ketonen, K. (1993) Yliopiston huomen. Korkeakoulupolitiikan historiallinen suunta Suomessa. Hanki ja jää.

KM 1972: B57. Kesäyliopistotyöryhmän mietintö.

KM 1962: 34. Kesäyliopistokomitean mietintö.

KM 1972: A17. Filosofisten ja yhteiskuntatieteellisten tutkintojen toimikunnan mietintö. Opetusministeriö.

KM 1981: 36. Avoimen korkeakoulun toimikunnan mietintö. Opetusministeriö.

Koro, J. (1989) Kasvatustieteen monimuotoopetuskokeilu Jyväskylän yliopistossa. Korkeakoulutieto 4, 52-54.

Koro, J. (1993) Aikuinen oman oppimisensa ohjaajana. Itseohjautuvuus, sen kehittyminen ja yhteys oppimistuloksiin kasvatustieteen avoimen korkeakouluopetuksen monimuotokokeilussa. Jyväskylä studies in education, psychology and social research 98.

KOTA-tietokanta. http://www.csc.fi/kota/ kota.html

Laakko, R. (1974). Yliopiston muuttuneet tehtävät: Tampereen yliopiston täydennyskoulutuskeskus. Tampereen yliopiston opintotoimiston tutkimuksia ja selvityksiä 18 .

Larsen, S. (1987) Helsingin yliopisto monimuoto-opetusta kehittämässä. Korkeakoulutieto $4,28-30$.

Larsen, S. (1988) Miksi Helsingin yliopisto järjestää avointa korkeakouluopetusta? Teoksessa Sivistys ja rakennemuutos -seminaari. 26.4.1988. Helsingin yliopisto. Vapaan sivistystyön toimikunta, 7-8.

Lindqvist, K. (1994) Avoimen yliopiston ohjausja neuvontajärjestelmän kehittäminen. Teoksessa J. Kyhäräinen (toim.) Helsingin avoin yliopisto nyt ja tulevaisuudessa. Helsingin avoin yliopisto, 28-31.

Mannerkoski, M. (1979) Korkeakoulutasoisen opetuksen avoimuus. Oulun yliopiston 21. lukuvuoden avajaispuhe 3.9.1979.

OPM 1983. Valtioneuvoston 6.1.1983 vahvistama korkeakoululaitoksen kehittämissuunnitelma 1983-1986. Korkeakoulu- ja tiedeosasto. Valtion painatuskeskus.

OPM (1984). Avoimen korkeakouluopetuksen järjestäminen korkeakouluissa 1984. Ope- 
tusministeriön ohje korkeakouluille 30.5.1984.

OPM (1986). Avoimen korkeakouluopetuksen rahoitusjärjestelyt vuonna 1986. Opetusministeriön ohje korkeakouluille 11.3.1986.

OPM 1989: 59.69 toimenpidettä aikuiskoulutuksen kehittämiseksi. Aikuiskoulutuksen johtoryhmän muistio. Opetusministeriön työryhmien muistioita.

OPM 1993. Koulutuksen ja korkeakouluissa harjoitettavan tutkimuksen kehittämissuunnitelma vuosille 1991-1996. Valtioneuvoston päätös 18.6.1993. Tabloid.

OPM 1996: 7. Avoin yliopisto-opetus väylänä korkeakoulututkintoon työryhmän muistio. Opetusministeriön työryhmien muistioita. Yliopistopaino.

OPM 2002: 26. Yliopistojen tulosohjauksen kehittämistyöryhmä II. (http://www.minedu.fi/ julkaisut/julkaisusarjat/työryhmämuistiot. html -> Yliopistojen tulosohjauksen...)

OPM 2002: 3. Parlamentaarisen aikuiskoulutuskomitean mietintö. Opetusministeriön työryhmien muistioita. (http://www.minedu.fi/ julkaisut/julkaisusarjat/työryhmämuistiot. html -> Parlamentaarisen...)

OPM 2003: 27. Korkeakoulujen opintoaikojen lyhentämisen toimenpideohjelma. Opetusminsiteirön työryhmämuistioita ja selvityksiä. (http://www.minedu.fi/julkaisut/julkaisusarjat/työryhmämuistiot.html -> Korkeakoulujen opintoaikojen...)

Perry, W. (1976) Open University. A personal account by the first Vice-Chancellor. Milton Keynes: the Open University Press.

Piesanen, E. (1996) Avoin yliopisto nuoren aikuisen uranäkemyksen muotoutumisessa. Koulutuksen tutkimuslaitoksen julkaisuja A 67. Jyväskylän yliopisto.

Puttonen, H. (1995) Avoimen yliopiston monimuotoiset motiivit. MALU-projektin lähtökohdat ja opiskelijatutkimus. Jyväskylän yliopiston avoimen yliopiston tutkimuksia 2.

Rantavaara, I. (1973) Englannin avoimen yliopiston kuulumisia. Kanava 1( 85), 297-299.

Relander, T. (1992) Selvitysmiehen raportti työttömyydestä ja työllistämisestä. 14.9.1992.

Rinne, R., Jauhiainen, A., Tuomisto, H., AlhoMalmelin, M., Halttunen, N. \& Lehtonen, K. (2003) Avoimen yliopiston opiskelija: Ko- kovartalokuvasta eriytyneisiin muotokuviin. Turun yliopiston kasvatustieteiden tiedekunnan julkaisuja A 200.

Rinta-Kanto, J. (1980) Turun yliopiston avoimen korkeakoulun kokeilu. Kansanopisto 8, 11-13.

Ryönänkoski, U. (1996) Helsingin seudun kesäyliopisto 30 vuotta. Yliopistopaino.

SA 83/1993. Opetusministeriön päätös avoimesta korkeakouluopetuksesta korkeakouluissa perittävistä maksuista.

Seppälä, K. (1983) Avointa korkeakoulua ohjaavasta päätöksenteosta. Turun yliopiston hallintoviraston julkaisuja 3. Opintoasiaintoimisto. Turun yliopisto.

Seppälä, K. (1994) Koulutusyksiköistä osaamisverkostoihin. Korkeakoulujen täydennyskoulutuskeskusten muutoksesta. Osa I. Oheistoiminnasta laajaksi tehtäväkokonaisuudeksi. Koulutus- ja tiedepolitiikan linjan julkaisuja 15A. Opetusministeriö.

Sundqvist, U. (1972) Avoin ja traditionaalinen yliopisto. Teoksessa Avoin yliopisto. Alustuksia ja esitelmiä Länsi-Suomen kesäyliopiston seminaarissa Raumalla 12.-13.6. 1972. Länsi-Suomen korkeakouluyhdistys. Oy Kehitys, 6-10.

Suuntana sivistys. Suomen ylioppilaskuntien liiton näkemys hyvästä koulutusjärjestelmästä. 2003.

Tuomikoski, P. (1980) Avoin korkeakoulu avoimeksi. Opistolehti 7, 194.

Tuominen, Vesa. (1982) Arvosanaopetuksesta saatuja kokemuksia ja arviointeja. Kansanopisto 1, 11-14.

Varila, J. (1990) Monimuoto-opiskelija avoimessa korkeakouluopetuksessa. Sosiodemografiset ominaisuudet, osallistumissyyt ja monimuoto-opetuksen arviointi. Helsingin yliopiston Lahden tutkimus- ja koulutuskeskuksen tutkimuksia 1. Yliopistopaino.

Yliopistotieto 1998/1. Suomen virtuaalinen avoin yliopisto. Kehittämispäällikkö Kirsti Kylä-Tuomolan haastattelu.

Ylioppilaslehti 1995/16. Avoin yliopisto lihoi liikaa. (Miira Lähteenmäki.)

Artikkeli saapui toimitukseen 12.5.2004. Se hyväksyttiin julkaistavaksi toimituskunnan kokouksessa 10.1.2005. 